\title{
MARKET ORIENTATION, ENTREPRENEURSHIP ORIENTATION, AND COMPANY PERFORMANCE: STUDY ON SMALL AND MEDIUM INDUSTRIES (SMES) FURNITURE IN DEMAK DISTRICT
}

\author{
Totok Wibisono ${ }^{1}$ \\ Nuria Universari ${ }^{2}$ \\ Yuli Budiati ${ }^{3}$
}

Faculty of Economics, Universitas Semarang

\begin{abstract}
The objectives of this research were to examine the effect of market orientation and entrepreneurial orientation toward firm performance. The populations of this study were small and medium enterprises (SMEs) in Demak regency. The sample were the furniture industry SMEs. This is a survey type of questionnaire based research. Sample size of the study is 86 and the data collection technique with purposive sampling. The data analysis used was PLS (Partial least Square). The research result showed that market orientation and entrepreneurial orientation have a positive effect on firm performance. It was evident that market orientation and entrepreneurial
\end{abstract}

Keywords: Market Orientation, Entrepreneurial Orientation, Firm Performance, Small and Medium Enterprises.

\footnotetext{
1 totok@usm.ac.id; Faculty of Economics, Universitas Semarang

2 nuria@usm.ac.id; Faculty of Economics, Universitas Semarang

3yulibudiati@usm.ac.id, Faculty of Economics, Universitas Semarang
}

P-ISSN: 2580-6084; E-ISSN: 2580-8079 


\section{INTRODUCTION}

Small and Medium Industry known as SMEs. The existence of Small and Medium Industries in Indonesia plays a role in the main contributor to the manufacturing sector because of its superiority as a labor-intensive industrial subsector and has supplied the needs of the domestic market (www.kemenperin.go.id). SMEs also plays a role in providing employment opportunities for the people of Indonesia.

Demak Regency is an area that has natural resource diversity and provides opportunities for SMEs to contribute to regional economic growth by utilizing these natural resources. One of the SME sectors that are developing and becoming the leading sector in the Demak Regency is the furniture industry. Table 1 shows that SME furniture plays an important role in contributing to the local economy to absorb the labor force amounted to 2,061 in 2014.

Table 1.

Sectors Leading Industry in Demak

\begin{tabular}{llllll}
\hline No & Sector & Year 2010 & & Year 2014 & \\
& & Business Unit & Labor & Business Unit & Labor \\
\hline 1 & Furniture / Furniture & 248 & 780 & 372 & 2,061 \\
2 & Processing of Fish & 296 & 705 & 606 & 1,252 \\
3 & Processing & 627 & 2,044 & 1,431 & 5,119 \\
4 & Industrial Garment & 244 & 2,556 & 712 & 2,056 \\
\hline
\end{tabular}

Source: Department of Industry and Trade Demak city, 2015

Although the furniture SMEs are one of the leading sectors in the Demak Regency, from 2013 until 2015 its production has decreased. The total production of the furniture industry in 2014 decreased by $8.0 \%$ and in 2015 it was $1.1 \%$. Table 2 shows the decline in furniture industry production in Demak Regency.

Table 2.

Number of Furniture Industry Production in Demak

\begin{tabular}{lllll}
\hline No & Year & Business Unit & Production & Growth \\
\hline 1 & 2013 & 371 & 520,987 & \\
2 & 2014 & 396 & 520,945 & $-8.0 \%$ \\
3 & 2015 & 372 & 520,887 & $-1,1 \%$ \\
\hline
\end{tabular}

Source: Disperindag of the city of Demak and www.bps.go.id

To overcome the problem of decreasing production of the furniture industry in the Demak Regency, the research team was interested to find out the factors that influence the performance of small and medium scale companies engaged in the furniture industry. 
Based on the potential of the furniture SMEs in the Demak Regency, it is proper for the government to pay real attention so that the furniture SMEs still exist amid increasingly fierce competition. Besides that, SME furniture needs to apply the concept of marketing by the scale of the furniture business. Ionita (2012) and Kraus et al. (2010) illustrates that marketing concepts that are appropriate to the characteristics of small and medium-sized businesses are needed.

Previous studies have shown the importance of market orientation and entrepreneurial orientation on company performance (eg Bucktowar et al., 2015; Hussain et al., 2016; Merio and Auh, 2009; Wijesekara et al., 2014). Market orientation(market orientation) and the orientation of entrepreneurship (entrepreneurial orientation) is part of the strategic orientation, the second component of the strategic orientation is intangible resources that guarantee the company survive in the long term and encourage the achievement of superior performance (Herath and Mahmood, 2014 and Ruokonen and Saarenketo, 2009 in Hussain et al., 2016). According to Morgan et al. (2015), a combination of market orientation and entrepreneurial orientation components will improve company performance compared to companies that do not implement both orientations. This study tries to apply the model by examining the effect of market orientation and entrepreneurial orientation on company performance in the context of furniture Small and Medium Industries (SMEs) in Demak district.

From the background that has been raised, the research question to be examined is:

1. Is there an influence of market orientation on company performance?

2. Is there an influence of entrepreneurial orientation on company performance?

\section{THEORETICAL BACKGROUND}

\section{Market Orientation}

Market orientation is a series of concrete actions taken by the company (it can also be said as a fundamental culture) that allows companies to maintain variations in market demand and supply and provide appropriate responses to various changes that occur (Varadarajan and Jayachandaran, 1999). Market orientation can be seen from two perspectives. From a cultural perspective, market orientation is a cognitive process that includes cultural dimensions such as the values and norms adopted by companies. While from a behavioral perspective, market orientation is the process of gathering market 
information.

Narver and Slater (1990) state that market orientation is a very effective and efficient organizational culture in creating behavior that is important in creating superior value for customers and further creating a superior performance for companies. According to Narver and Slater (1990), market orientation is an organizational culture manifested as customer orientation, competitor orientation, and coordination among existing functions. The intended organizational culture is based on two criteria, namely: focused on the long term and aims to generate profits. Meanwhile Jawworski and Kohli (1990) view market orientation as organizational behavior in implementing marketing concepts. This behavior is emphasized in activities that comprise customer needs, dissemination of intelligence to all departments, and responsiveness.

Baker and Sinkula (2009) argue that market orientation is indicated by the tendency of companies to adopt marketing concepts and commit to using market orientation as a basis for strategic decision making. Naver and Slater (1990) assert that market orientation pays close attention to both customers and competitors.

Entrepreneurial Orientation

Hult et al. (2004) and Lumpkin and Dess (1996) in Wijesekara et al. (2014) states that entrepreneurial orientation is a process, practice and decision making activity that leads to entrepreneurship. Drucker (1994) defines an entrepreneurial orientation as a character or trait attached to the real business world and can develop them with resilience. Entrepreneurial orientation seeks to create value for themselves and their environment (Venkataraman and Saras, 2001) and create something new and different (Hisrich et al., 2005 and Kasmir, 2006).

According to Covin and Slevin (1989), entrepreneurial orientation consists of the risk dimension (the extent to which top managers tend to take risks related to business), the innovation dimension (supporting change and innovation to gain a competitive advantage for companies), and the proactive dimension (competing aggressively with other companies). Miller (1983) explains that entrepreneurial orientation is an orientation to be the first in terms of innovation in the market, have an attitude to take risks and are proactive towards changes that occur in the market. In Miller's (1983) view, entrepreneurial orientation can be determined based on three dimensions, namely proactive, innovative, and risk-taking. 
Company

Performance Performance is the level of success in carrying out the tasks and the ability to achieve the goals set (Gibson et al., 1997). In the organizational performance literature model, several aspects are used as indicators to measure organizational performance. According to Brett (2000) in Wijesekara et al. (2014), company performance covers three main aspects, namely output or performance operating (for example finance, productivity, and efficiency), outcome or delivery performance (eg effectiveness, strategy, and quality) and process performance (involving both operating performance and delivery performance).

Venkatraman and Ramamujam (1986) state that company performance using perspective is operational performance measured through market share, new product introductions, marketing effectiveness, and various measures of technological efficiency related to business performance. Whereas Hart and Banbury (1994) divide operational performance into two dimensions, namely 1) indicators relating to sales growth and market share in existing businesses 2) indicators related to the company's position in the future. Business performance can also be seen from customer satisfaction, customer loyalty, sales growth, and profitability (Day and Wensley, 1988).

The Relationship Between Market Orientation and Company Performance Marketing, and more specifically market orientation, are identified as variables that contribute importantly to business performance (Deshpande et al., 1993; Jaworski and Kohli, 1993; Narver and Slater, 1990 in (Jones \& Rowley, 2011). Some literature shows that market orientation has a positive effect on organizational performance (Kara et al., 2005 (Wijesekara et al., 2014). Idar and Mahmood's research (2011) shows a positive relationship between market orientation and the performance of companies engaged in finance. While Long's research (2013) proves that market orientation has a positive influence on organizational performance in terms of market share growth, sales growth, and profitability growth. The assumptions underlying the empirical investigation of the influence of market orientation on company performance are market orientation provides a better understanding for the company regarding the environment and customers, thus enabling companies to create more value for customers (Kara, et al., 2005 in Wijesekara, Kumara \& Gunawardana, 2014). Based on studies that prove a positive relationship between market orientation and company performance, the first hypothesis in research 
These are as follows:

H1: Market orientation has a positive effect on firm performance relationship between orientation Entrepreneurship and Corporate Performance

Studies that show that entrepreneurial orientation can improve the performance of the business has been done, for example, research Covin and Slevin (1991), Lumpkin and Dess (2001), as well as Wiklund and Shepherd (2005).

Research conducted in Croatia shows that there is a positive relationship between entrepreneurial orientation owned by hotels in Croatia and performance as measured by the following criteria: level of sales, level of sales growth, cash flow, net income and ability to fund business growth from profits (Galetic and Milovanovic, 2004 in Mustikowati and Tysabri, 2014). Chow (2006) in his research showed a positive relationship between entrepreneurial orientation and company performance. Madsen's research (2007) also provides empirical evidence that entrepreneurial orientation has a positive effect on company performance. Based on these studies, the second hypothesis proposed in this study are as follows:

$\mathrm{H} 2$ : entrepreneurial orientation has a positive effect on company performance

\section{METHOD, DATA AND ANALYSIS}

In this study, the population is small and medium-sized business owners who are in Demak. The sample is small and medium entrepreneurs in Demak Regency, which is engaged in the furniture industry. The sampling technique used in this study was purposive sampling.

The data used in this study are primary and secondary. Primary data were obtained from furniture entrepreneurs in Demak Regency. Secondary data was obtained through the data of the Demak City Industry and Trade Office in the form of furniture businessmen data in Demak. Data collection methods in this study were conducted by questionnaire.

The research variables used in this study are market orientation, entrepreneurial orientation, and company performance. The indicators used to measure market orientation, entrepreneurial orientation, and company performance can be seen in Table below. 
Tabel 3

Variables and Indicators

\begin{tabular}{|c|c|c|}
\hline Variables & Dimensions & Indicators \\
\hline Market & Customer & Commitment (A1-1) \\
\hline \multirow[t]{7}{*}{ Orientation } & \multirow[t]{3}{*}{ Orientation } & Creation of customer value (A1-2) \\
\hline & & Understanding customer needs (A1-3) \\
\hline & & Customer satisfaction goals (A1-4) \\
\hline & \multirow{4}{*}{$\begin{array}{l}\text { Competitor } \\
\text { Orientation }\end{array}$} & Salespeople share competitor information \\
\hline & & $(\mathrm{A} 2-1)$ \\
\hline & & React quickly to competitor's actions (A2-2) \\
\hline & & $\begin{array}{l}\text { Target opportunities for competitive } \\
\text { advantage (A2-3) }\end{array}$ \\
\hline Entrepreneurship & \multirow[t]{4}{*}{ Innovation } & Attention in research and development, \\
\hline Orientation & & technology leadership, and innovation (B1-1) \\
\hline \multirow[t]{7}{*}{ Variables } & & $\begin{array}{l}\text { Many offer lines (types / quantities) of new } \\
\text { products or new services (B1-2) }\end{array}$ \\
\hline & & $\begin{array}{l}\text { Changes in product lines and services have } \\
\text { been carried out quite dramatically (B1-3) }\end{array}$ \\
\hline & Proactive & 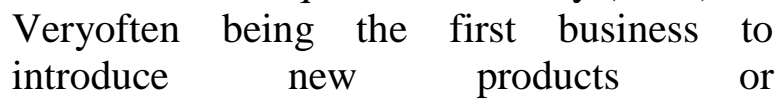 \\
\hline & & $\begin{array}{l}\text { services,techniques administrative, } \\
\text { technology, operations (B1-4) }\end{array}$ \\
\hline & \multirow[t]{3}{*}{ Risk } & $\begin{array}{l}\text { Types that take } 1 \text { an intense competition } \\
\text { before the competition itself (B1-5) }\end{array}$ \\
\hline & & $\begin{array}{l}\text { strong tendency to accept the project - high- } \\
\text { risk projects (with the possibility of very } \\
\text { high returns) (B1-6) }\end{array}$ \\
\hline & & $\begin{array}{l}\text { Adjust to the environment, bold and } \\
\text { comprehensive action is needed to achieve } \\
\text { company goals (B1-7) }\end{array}$ \\
\hline Company & - & growth volume Sales $(\mathrm{C} 1-1)$ \\
\hline Performance & & $\begin{array}{l}\text { Profit growth }(\mathrm{C} 1-2) \text { Successful } \\
\text { new products }(\mathrm{C} 1-3)\end{array}$ \\
\hline
\end{tabular}

Data analysis methods used in this study used structural equation modeling techniques based on variance or component known as Partial Least Square (PLS).

\section{RESULTS AND DISCUSSION}

\section{Test Results Measurement Model (Outer Model)}

Evaluation of the outer model or evaluation of the measurement model is done to assess the validity and reliability of the model. Measurement models with reflective indicators are evaluated by looking at values convergent validity and discriminant 
validity for indicators forming latent constructs, as well as through composite reliability and Cronbach alpha for the indicator blocks (Ghozali, 2011). Validity is Convergent related to the principle that the gauges of a construct should be highly correlated. Validity test Convergent can be seen from the value of AVE (Average Variance Extracted) and the value of the loading factor for each indicator.

AVE assessment criteria must be above 0.50. While the assessment criteria loading factor for evaluating the reflective measurement model are stated to be high if the value is more than 0.7 , however, the value $0.50-0.60$ is still acceptable as long as the model is still in the development stage. By using PLS (Partial Least Square) version 3.0, the AVE values are obtained as follows:

Table 4.

Average Variance Extracted

\begin{tabular}{ll}
\hline Variables /Dimensions & AVE \\
\hline Company Performance & 0.468 \\
Entrepreneurial & 0.288 \\
OrientationMarket & 0.249 \\
OrientationCustomer & 0.441 \\
OrientationCompetitor Orientation & 0.437 \\
\hline
\end{tabular}

Source: Primary data processed, 2017

Results Table 4. shows that the AVE value of each construct is less than 0.50 so that almost all constructs do not correspond to the required AVE value. Another way to test the validity convergent of reflective indicators is to look at the values loading factor for each indicator. Value Factor loading of each indicator data processing results are as follows:

Table 5.

Loading Factor

\begin{tabular}{ll}
\hline Indicator & Loading Factor \\
\hline A1-1 & 0.687 \\
A1-2 & 0.513 \\
A1-3 & 0.734 \\
A1-4 & 0.702 \\
A2-1 & -0.032 \\
A2-2 & 0.894 \\
A2-3 & 0.715 \\
B1-1 & 0.540 \\
B1-2 & 0.693 \\
B1-3 & 0.657 \\
B1-4 & 0.492 \\
\hline
\end{tabular}




\begin{tabular}{ll}
\hline B1-5 & -0.317 \\
B1-6 & -0.174 \\
B1-7 & 0.662 \\
C1-1 & 0.575 \\
C1-2 & 0.564 \\
C1-3 & 0.869 \\
\hline
\end{tabular}

Source: primary data is processed, 2017

From table 5 it can be seen that the loading factors of the indicators A2-1, B1-4, B1-5, and B1-6 are below 0.50. So these indicators must be eliminated from the model and not included in hypothesis testing because it has convergent validity a low-value.

After the indicators that have a loading factor below 0.5 have been eliminated, the program runs again. The results are as follows:

Table 6.

Factor Loading Second Stage

\begin{tabular}{ll}
\hline Indicator & LoadingFactor \\
\hline A1-1 & 0.683 \\
A1-2 & 0.501 \\
A1-3 & 0.730 \\
A1-4 & 0.715 \\
A2-2 & 0.880 \\
A2-3 & 0.744 \\
B1-1 & 0.560 \\
B1-2 & 0.659 \\
B1-3 & 0.742 \\
B1-7 & 0.747 \\
C1-1 & 0.546 \\
C1-2 & 0.540 \\
C1-3 & 0.887 \\
\hline
\end{tabular}

Source: Primary data processed, 2017

After the second stage of data processing, the loading factor for all indicators meets convergent validity that is all above 0.05 . Testing validity discriminant can be done by looking at the AVE square root value with the correlation between constructs.validity of the test results in Discriminant using the comparative value of the square root of AVE by correlations among constructs can be seen in Table 7 . 
Table 7.

AVE Square Root Value and Inter-Construct Correlation

\begin{tabular}{|c|c|c|c|c|c|c|}
\hline & $\begin{array}{l}\text { Company } \\
\text { Performance }\end{array}$ & $\begin{array}{l}\text { Moderating } \\
\text { Effect } 1\end{array}$ & Entrepreneurship & $\begin{array}{l}\text { Orientation } \\
\text { Market }\end{array}$ & $\begin{array}{l}\text { Orientation } \\
\text { Customer }\end{array}$ & $\begin{array}{l}\text { Orientation } \\
\text { Competitor } \\
\text { Orientation }\end{array}$ \\
\hline $\begin{array}{l}\text { Company } \\
\text { Performance }\end{array}$ & 0.678 & & & & & \\
\hline $\begin{array}{l}\text { Moderating } \\
\text { Effect } 1\end{array}$ & 0,047 & 1,000 & & & & \\
\hline Enterprise & OOrientation,502 & 0.172 & 0.681 & & & \\
\hline $\begin{array}{l}\text { Orientation } \\
\text { Market }\end{array}$ & 0.564 & -0.153 & 0.360 & 0.535 & & \\
\hline $\begin{array}{l}\text { Customer } \\
\text { Orientation }\end{array}$ & 0.105 & -0.053 & 0.195 & 0.718 & 0.664 & \\
\hline $\begin{array}{l}\text { Orientation } \\
\text { Competitor }\end{array}$ & 0.693 & -0.179 & 0.333 & 0.787 & 0.137 & 0.815 \\
\hline
\end{tabular}

Source: primary data is processed, 2017

Table 7 shows that constructs that have a value of roots AVE quadrant greater than the correlation value between constructs and other constructs in the model are the construct of entrepreneurial orientation and competitor orientation. Thus, only the construct of entrepreneurial orientation and competitor orientation has good discriminant validity.

Another way to test discriminant validity is to look at the value cross-loading. The correlation value of the indicator to its construction must be greater than the value of the correlation between the indicator and other constructs. The following are the results of cross-loading indicators between constructs.

Table 8.

Cross Loading inter-Construct Indicators

\begin{tabular}{lllll}
\hline & Corporate Performance & EnterpriseOrientation & Customer Orientation & OrientationCompetitor \\
\hline A1-1 & 0.132 & 0.137 & 0.683 & 0.046 \\
A1-2 & 0.125 & 0.081 & 0.501 & -0.022 \\
A1-3 & -0.011 & 0.030 & 0.730 & 0.078 \\
A1-4 & 0.062 & 0.241 & 0.715 & 0.203 \\
A2-2 & 0.752 & 0.350 & 0.167 & 0.880 \\
A2-3 & 0.315 & 0.168 & 0.036 & 0.744 \\
B1- & 0.146 & 0.560 & 0.308 & 0.465 \\
B1-2 & 0.1590 .227 & 0.659 & & 0.443 \\
B1-3 & 0.264 & 0.742 & 0.087 & 0.059 \\
B1-7 & 0.266 & 0.747 & 0.108 & 0.100 \\
C1- & -0.0030 .193 & 0.223 & & 0.546 \\
C1-2 & 0.540 & 0.266 & -0.047 & 0.195 \\
C1-3 & 0.887 & 0.464 & 0.145 & 0.731 \\
\hline
\end{tabular}

Source: primary data is processed, 2017

Table 8 shows that the value of the Corporate performance loading indicator has a value greater than the correlation value of performance indicators of the Company and other constructs. Likewise for the construct of Entrepreneurship Orientation, Customer Orientation, and Competitor Orientation. This means that all constructs have good discriminant validity. 
The reliability test of a construct with reflective indicators can be done in two ways, namely composite reliability and Cronbach's alpha. Value Composite reliability and Cronbach's alpha for all constructs can be seen in Table 9.

Table 9.

Composite Reliability and Cronbach Alpha

\begin{tabular}{lll}
\hline Variable / Dimension & Composite Reliability & Cronbach Alpha \\
\hline Company Performance & 0.706 & 0.575 \\
Entrepreneurship Orientation & 0.744 & 0.628 \\
Market Orientation & 0.694 & 0.521 \\
Customer Orientation & 0.755 & 0.578 \\
Competitor Orientation & 0.797 & 0.504 \\
\hline
\end{tabular}

Source: Primary data processed, 2017

The test results composite reliability shows that all constructs have a Cronbach's alpha value of less than 0.60 except for the entrepreneurial orientation construct a value of 0.628. So that almost all constructs do not meet the required criteria or are less reliable. But the value of Cronbach's alpha is not used as the main indicator in assessing the reliability of the construct because according Ghozali ((2011), using Cronbach's alpha likely to give a lower value(lower bound estimate)so it is advisable to use composite reliability in testing the reliability of a construct.

The test results in the reliability of the construct using values composite reliability show the results above 0.60 . this means that all of the constructs are the performance of the company, entrepreneurial orientation, market orientation, customer orientation, and competitor orientation meets the required criteria or reliability.

Structural Model Test Results (Innermodel)

Testing inner models by researchers to look at $R$ Square for any endogenous latent variables as the predictive power of the model structural parameters and see the results of the coefficient path and the significance level. The value of $R$ Square is the testing goodness of fit model results. The results of these tests is seen in the following table: 
Table 10.

Value of $R$ Square

\begin{tabular}{ll}
\hline Construct & Value $^{2}$ \\
\hline Company Performance & 0.424
\end{tabular}

Source: Primary data processed, 2017

Test results $R$ Square for the construct of Company Performance amounted to 0.424. It means that the variability of the constructs of the Company's performance that can be explained by the constructs of Market Orientation, Entrepreneurial Orientation, Customer Orientation, Competitor Orientation, and its interactions is $42.4 \%$.

Test the relationship between constructs by looking at the results of the parameter coefficients path and their level of significance. Through calculation bootstrapping, the following values are obtained:

Table 11.

Path Coefficients (Mean, STDEV, T-Values)

\begin{tabular}{lllll}
\hline \multicolumn{1}{c}{ Original } & Sample & Standard Deviation T & Statistics \\
\hline OP $\rightarrow 0,455$ & 0,423 & 0,217 & 2,100 & 0,018 \\
OK $\rightarrow 0,328$ & 0,351 & 0,115 & 2,854 & 0,002
\end{tabular}

Source: primary data is processed, 2017

The test of the relationship between the construct indicates that the construct Market Orientation positive effect on the Company's performance with coefficient parameters at 0.455 and significant at the $5 \%$ (t count is greater than 1.96). Likewise, the construct of Entrepreneurship Orientation has a positive effect on Company Performance with a parameter coefficient of 0.328 and significant at $5 \%$ ( $\mathrm{t}$ count greater than 1.96 ).

Hypothesis 1 test results show that market orientation has a positive effect on firm performance. These results are in line with the research of Hussain et al. (2016) which states that SME respondents involved in their research pay high attention in adopting and practicing market orientation in meeting customer needs to produce the best company performance and win in the competition.

The results of testing Hypothesis 1 are also in line with what happened in the field. Respondents' responses to the indicators of market orientation variables on the dimensions of customer orientation show that the indicators are trying to meet customer needs and the indicators aim to satisfy customers produces a fairly high average value of 
4,349 and 4,465. This means that furniture SMEs in Demak have an interest in activities to meet customer needs and satisfy customers, even though responding to competitors' actions is slower than the response of business actors to customers. This is indicated by the average value of respondents for indicators of competitor orientation dimensions smaller than the average value of respondents for indicators of customer orientation dimensions.

Narver and Slater (1990) state that customer orientation and competitor orientation involve all activities involved in finding information about customers and competitors, then the information is disseminated to all parts of the business. Thus business actors need to pay attention to both of these orientation dimensions to maximize company performance. Narver and Slater (1990) also state that market orientation is a business philosophy that is seen to be effective and efficient in creating the behavior needed to create superior value for buyers which will ultimately affect business performance sustainably.

Hypothesis 2 test results show that entrepreneurial orientation has a positive effect on firm performance. The results of this hypothesis test are in line with the research of Wijesekara et al. (2014). Wilkund (1990) and Madsen (2005) in Wijesakara et al. (2014) states that entrepreneurial-oriented companies are generally more effective in improving company performance.

The results of this study are also in line with the results of the study of Yi et al. (2008) and Keh et al. (2007) who found that there was a positive relationship between entrepreneurial orientation and company performance. Dess et al. (1997) in Benito et al. (2008) states that an entrepreneurial orientation in terms of business opportunity opportunities is very necessary to improve performance in the face of an uncertain competitive environment. Likewise for furniture business operators in Demak who face competitors not only in Demak but also in Jepara district.

The results of this test also illustrate that the better the entrepreneurial orientation possessed by furniture business actors in Demak such as innovative behavior, proactive behavior, and risk-taking, the better the performance of the company. An increasingly strong entrepreneurial orientation will help companies create innovations, open up opportunities to create new markets, and dare to take risks to increase competitiveness. 


\section{CONCLUSIONS}

Based on the results of hypothesis testing, the following conclusions can be concluded:

1. Market orientation has a positive effect on company performance. Market orientation is formed from the dimensions of customer orientation and competitor orientation.

2. Entrepreneurial orientation has a positive effect on company performance. Market orientation variables include innovative behavior, proactive behavior, and risktaking

\section{IMPLICATIONS}

Implications that can be given from this research are:

1. Application of market orientation and entrepreneurial orientation is the key so that the quality of performance in running a business is better. Therefore, SME Furniture in Demak Regency needs to increase the dimensions of market orientation which include customer orientation and competitor orientation as well as an entrepreneurial orientation which includes innovative behavior, proactive behavior, and risk-taking.

2. Furniture SME entrepreneurs should remain sensitive to competitors because competition conditions can be tighter. Besides that, the scope of competitors must be expanded not only in the Demak district but also in furniture center areas outside the region such as Jepara in Central Java, Pasuruan in East Java, or Indramayu in West Java.

3. This research was conducted using a quantitative approach. It would be better if done using a qualitative approach so that the dimensions of market orientation and entrepreneurial orientation can be explored more deeply.

\section{REFERENCES}

Anonymous (2015), Department of Industry and Trade of Demak City. Anonymous (2015), www.bps.go.id.accessed January 6, 2017.

Baker, WE and Sinkula, JM (2009), "The Complementary Effects of Market Orientation and Entrepreneurial Orientation on Profitability in Small Businesses," Journal of Small Business Management, Vol. 47, No. 4, pp. 443-464. 
Benito, O. G, Benito, JG and Gallego, PAM (2008), "Role of Entrepreneurship and Market Orientation in Firm Success," European Journal of Marketing, Vol. 43, No. 3-4, pp. 500-522.

Bucktowar, R., Kocak, A. and Padachi, K. (2015), "Entrepreneurial Orientation, Market Orientation, and Networking: Impact on Innovation and Firm Performance," Journal of Developmental Entrepreneurship, Vol. 20, No. 4, pp. 122.

Covin, JG, and Slevin, DP (1989), "Strategic Management of Small Firms in Hostile and Benign Environments," Strategic Management Journal, Vol. 10, No. 1, pp. 75-87.

Drucker, PF (1994), Innovation and Entrepreneurship, Practice, and Principles. Jakarta: Surge Script.

Chow, IH (2006), "The Relationship between Entrepreneurial Orientation and Firm Performance in China," SAM Advanced Management Journal, Vol. 71, No. 3, pp. $11-20$.

Covin, JG, and Slevin, DP (1991), "A Conceptual Model of Entrepreneurship as Firm Behavior," Entrepreneurship Theory and Practice, Vol. 16, pp. 7-25.

Cooper, DR, and Schindler, PS (2008), Business Research Methods. New York, NY: McGraw-Hill / Irwin.

Day, GS and Wensley, R. (1988), "Assessing Advantage: A Framework for Diagnosing Competitive Superiority," Journal of Marketing, Vol. 52, No. 2, pp. 1-20.

Ferdinand, A. (2011), Management Research Methods. Semarang: Diponegoro University Publisher Agency.

Ghozali, I. (2011), Structural Equation Modeling Alternative Methods with Partial Least Square (PLS). Semarang: Diponegoro University Publisher Agency.

Gibson, JL, Ivancevich, JM and Donnely, JH (1997), Organization and Management: Behavior, Structure, Process. Erlangga: Jakarta.

Hart, S. and Banbury, C. (1994), "How Strategy-Making Processes Can Make A Difference," Strategic Management Journal, Vol. 15, No. 4, pp. 251-269.

Hisrich, Rt. D., Michael, PP and Dean, AS (2005), Entrepreneurship. International Edition, McGraw Hill, New York: USA.

Hussain, J., Rahman, W. and Shah, FA (2016), "Market Orientation and Performance: The Interaction Effect of Entrepreneurial Orientation," Pakistan Journal of Commerce and Social Sciences, Vol. 10, No. 2, pp. 388-403.

Idar, R. and Mahmood, R. (2011), "Entrepreneurial and Market Orientation Relationships to Performance: The SME Perspective," Interdisciplinary Review of Economics and Management, Vol. 1, No. 2, pp. 1-8.

Ionita, D. (2012), "Entrepreneurial Marketing: A New Approach for Challenging Times", Management and Marketing, Vol. 7, No. 1, pp. 131-150.

Jaworski, BJ, and Kohli, AK (1993), "Market Orientation: Antecedents and Consequences," The Journal of Marketing, Vol. 57, No. 3, pp. 53-70.

Jones, R., and Rowley, J. (2011), "Entrepreneurial Marketing in Small Businesses," International Small Business Journal, Vol. 29, No. 1, pp. 25-36.

Keh, HT, Nguyen, TTM and Ng, HP (2007), "The Effects of Entrepreneurial Orientation and Marketing Information on The Performance of SMEs," Journal of Business Venturing, Vol. 22, No. 4, pp. 592-611.

Kraus, S., Harms, R. and Fink, M. (2010), "Entrepreneurial Marketing: Moving Beyond Marketing in New Ventures," International Journal of Entrepreneurship and Innovation Management, Vol. 11, No. 1, pp. 19-34. 
Li, Y., Zhao, Y., Tan, J., and Liu, Y. (2007), "Moderating Effects of Entrepreneurial Orientation on Market Orientation-Performance Linkage: Evidence from Chinese Small Firms," Journal of Small Business Management, Vol . 1, No. 9, pp. 182-198.

Long, HC (2013), "The Relationship among Learning Orientations, Market Orientations, Entrepreneurial Orientations, and Firm Performance of Vietnam Marketing Communications Firms," Philippine Management Review, Vol. 20, pp. 37-46.

Lumpkin, GT, and Dess, GG (2001), Linking Two Dimensions of EO to Firm Performance: The Moderating Role of Environment and Industry Life Cycle. Journal of Business Venturing. 16 (5), 429-451.

Madsen, EL (2007), "The Significance of Sustained Entrepreneurial Orientation on Performance of Firms - A Longitudinal Analysis," Entrepreneurship \& Regional Development, Vol. 19, No. 2, pp. 185-204.

Merlo, O. and Auh, S. (2009), "The Effects of Entrepreneurial Orientation, Market Orientation, and Marketing Subunit Influence on Firm Performance," Market Lett, Vol. 20, pp. 295-311.

Miller, D. (1983), "The Correlates of Entrepreneurship in Three Types of Firms," Management Science, Vol. 29, No. 7, pp. 770-791.

Morgan, T., Anokhin, S., Kretinin, A. and Frishammar, J. (2015), "The Dark Side of The Entrepreneurial Orientation and Market Orientation Interplay: A New Product Development Perspective," International Small Business Journal, Vol. 33, No. 7, pp. 731-751.

Mustikowati, RI dan Tysari, I. (2014), “Orientasi Kewirausahaan, Inovasi, dan Strategi Bisnis Untuk Meningkatkan Kinerja Perusahaan (Studi pada UKM Sentra Kabupaten Malang)," Modernisasi, Vol. 10, No. 1, pp.23-37.

Narver, JC and Slater, SF (1990), "The Effect of A Market Orientation on Business Profitability," The Journal of Marketing, Vol. 54, No. 4, pp. 20-35.

Shane, S. and Venkataraman, S. (2000), "The Promise of Entrepreneurship as a Field of Research," Academy of Management Review, Vol. 25, No.1, pp. 217-226.

Sutrisno, D. (2017), Pemerintah Dorong IKM Nasional Dobrak Pasar Global, www.republika.co.id diakses Tanggal 20 Februari 2017.

Wijesekara, WADS, Kumara, PAPS and Gunawardana, TSLW (2014), "Impact of Market Orientation and Entrepreneurial Orientation on Performance: A Study of Small and Medium Scale Garment Manufacturers in Sri Lanka," Proceedings of the 3ed International Conference on Management and Economics, Faculty of Management and Finance, University of Ruhuna, Sri Lanka, pp. 373-386.

Varadarajan, R. and Jayachandran, S. (1999), "Marketing Strategy: An Assessment of The State of The Field and Outlook," Journal of The Academy of Marketing Science, Vol. 27, No. 2, pp. 120-143.

Venkatraman, N. and Ramanujam, V. (1986), "Measurement of Business Performance in Strategy Research: A Comparison of Approaches," Academy of Management Review, Vol. 11, No. 4, pp. 801-814.

Venkataraman, S. and Saras, DS (2001), "Strategy and Entrepreneurship: Outlines of An Untold Story," Working Papers, No. 01-06.

Wiklund, J. and Shepherd, D. (2005), "Entrepreneurial Orientation and Small Business Performance: A Configurational Approach,"Journal of Business Venturing, Vol. 20, pp. 71-91. 